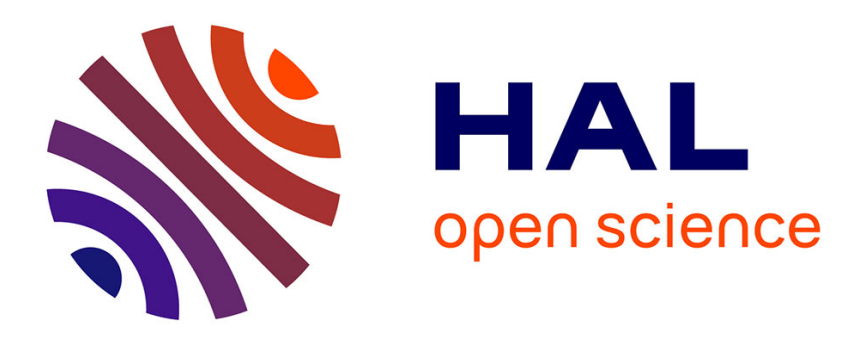

\title{
An Explanation of the Life Span of New French Firms
} Rafik Abdesselam, Jean Bonnet, Nicolas Le Pape

\section{To cite this version:}

Rafik Abdesselam, Jean Bonnet, Nicolas Le Pape. An Explanation of the Life Span of New French Firms. Small Business Economics, 2004, 10.1023/B:SBEJ.0000032034.59035.b4 . hal-02937310

\section{HAL Id: hal-02937310 https://hal.science/hal-02937310}

Submitted on 16 Sep 2020

HAL is a multi-disciplinary open access archive for the deposit and dissemination of scientific research documents, whether they are published or not. The documents may come from teaching and research institutions in France or abroad, or from public or private research centers.
L'archive ouverte pluridisciplinaire HAL, est destinée au dépôt et à la diffusion de documents scientifiques de niveau recherche, publiés ou non, émanant des établissements d'enseignement et de recherche français ou étrangers, des laboratoires publics ou privés. 


\section{An explanation of the life span of new French firms}

Rafik Abdesselam*, Jean Bonnet* and Nicolas Le Pape*

*GEMMA

Department of Economics, University of Caen,

Esplanade de la Paix, 14032 Caen, Cedex, France.

e-mails : $\underline{\text { Abdesselam@econ.unicaen.fr, Bonnet@econ.unicaen.fr, Lepape@econ.unicaen.fr }}$

October 2002 


\begin{abstract}
In contrast to previous studies on firm survival which tend to focus on features related to the structure of the firms and their area of activity, our aim here is to widen the perspective usually adopted in the field, taking into account a larger and more qualitative set of variables. Among these variables, features related to the individual characteristics of the entrepreneur, to the context of entrepreneurship and to the insertion in entrepreneurial networks are significant to explain the life span of new firms. The empirical material is drawn from two surveys, which provide detailed data about a group of new firms created in France in 1994 and closed down before 1997 or still running in 1997. Our empirical approach on qualitative data is based on data analysis methods (linear discriminant analysis, barycentric discriminant analysis, analysis of variance). According to the characteristics of the entrepreneur, the main explanatory factors for the survival of new firms are the fact that they are entrepreneurs who have taken over firms, that they have acquired during their previous occupational activity an experience in the same branch of activity and that they experience a successful integration into the entrepreneurial networks. These three factors show that the survival of young firms is indirectly conditioned by the existence of an initial custom, by the mastery of a job and by the know-how in the entrepreneurial function.
\end{abstract}

Keywords: Life duration of firms, entrepreneurship, data analysis methods.

JEL-code: C40, L10, L20 


\section{Introduction}

Since the eighties, the renewal of the productive system has shown a growing importance of small and medium sized enterprises (SMEs) as regards job creation ${ }^{1}$. Indeed, a period of economic recession characterized by an increased uncertainty and an intense technological renewal is more favourable to SMEs because they are more flexible and adaptable (Birch, 1983). This could partly explain the surge in entrepreneurship in the industrial and tertiary sectors ${ }^{2}$ in France. Furthermore, when unemployment is increasing, a growing number of unemployed people will decide to found their own firms.

The growth in the number of start-ups ${ }^{3}$ in France results from both the greater possibilities to start up a firm and a greater supply of entrepreneurs. On the one hand, new opportunities for the creation of new firms have appeared both in the tertiary and the industrial sectors thanks to restructuring, to the scattering policy of large industrial groups and also to the development of new needs in the tertiary sector. On the other hand, a high level of unemployment ${ }^{4}$ and a strong culture of entrepreneurship in some French regions have led to a growing supply of entrepreneurs.

The level of entrepreneurial activities is nevertheless much less important in France than in most industrialized countries ${ }^{5}$. The difference in the propensity for creating new firms refers mainly to the gap between an entrepreneurial society, which values private initiative and a wage society, which increases the opportunity cost for someone who wants to create a new firm. In an entrepreneurial society, being salaried does not give the insurance of a stable situation because of the large possibility for the employer to lay off and because of the poor unemployment benefits. In a wage society like in France, salaried workers have great historical advantages, with the social security, relative stability with preservation of jobs and the possibility to benefit from many public goods.

In the French economy, about fifty per cent of new firms disappear before five years. So it seems to be particularly important to examine the strengths and weaknesses of the specific population that is creating firms so as to elaborate appropriate policies to increase their rate of 
survival. Studies on firm survival mainly take into account characteristics relating to the firm to the branch of industry or to the business cycle ${ }^{6}$.

The purpose of this paper is, by using individual data, to investigate firm survival, by taking into account characteristics concerning the entrepreneur, the context of the entrepreneurship and the degree of insertion of the entrepreneur in the entrepreneurial networks. We analyze the life span of the firms thanks to a survey of entrepreneurship in France during the first six months of 1994, and a second survey of the same firms four years later.

The structure of the paper is as follows. In section 2, we give a measure of the intensity of entrepreneurship with important variables pertaining to the profile of the creator. In section 3 , we research the significant modalities of the variables which discriminate between the life span of the new firms.

\section{Intensity of Entrepreneurship}

\subsection{Data set}

We used a survey entitled Sine $94^{7}$, which was conducted by the French National Institute of Statistical and Economic Studies ${ }^{8}$ in 1994. This survey identifies qualitative data surrounding entrepreneurship and, more precisely, it contains variables related to the entrepreneur, to the context and to the environment of entrepreneurship. A second survey carried out in 1997 (Sine 97) gives us information about the state of the same firms (closed down or still running; when closed down, the date of the discontinuance of activity).

We retained 25682 independent enterprises which had been set up or taken over during the first half of 1994 (Sine 94). Firms set up by existing companies (subsidiaries) have been removed from the sample as well as team projects.

In these two surveys, new firms are identified on the basis of their registration in the Sirene repertory ${ }^{9}$. Financial and agricultural activities and the French units established abroad are set aside. The surveyed units belong to the private productive sector in the field of industry, building, trade and services. 
In the end, after the elimination of overseas departments, 23013 enterprises have been retained (representing 67293 corrected units ${ }^{10}$ ).

We use 29 variables presented in Annex 1 to determine the different survival factors of new firms ${ }^{11}$. In a first step, it is possible to explain the difference in the propensity of entrepreneurship and in the life span of new firms according to specific socio-economic characteristics of the entrepreneur.

\subsection{Socioeconomic characteristics, entrepreneurship and firms' survival}

Among the 47 million people resident in France aged over 15 in 1997, the proportion of new firm founders is about 5/1000. This global statistic covers great disparities according to classical socioeconomic features of the entrepreneur: sex, age, professional status, academic level, previous occupation and nationality (table I).

\section{Insert TABLE I}

We carry out homogeneity tests to measure whether the modalities of the 6 selected variables are divided up in an identical way in the two populations of firms: those which started in 1994 and those which are still alive in 1997. With tests comparing proportions, with a risk of error lower or equal to $5 \%$ (unilateral test), this analysis allows us to bring forth the modalities for which disparities appear. These disparities, even though constitutive of strong tendencies, may evolve in time (entrepreneurial cohorts are not identical across time) and bear some influence on the life duration of the firm.

The intensity of entrepreneurship tends to be related more to men than to women. Moreover, those firms created by men are rather "still running" than "closed down" after four years. Many studies tend to explain this under-performance of women because firms created by women are often small-sized, in risky sectors and on narrow markets (Du Rietz and Henrekson, 2000). 
According to the age, we can see that the intermediate categories show a greater intensity in entrepreneurship and that the lowest edged class is related to a shorter life duration of the firm. This feature may be explained by the lack of experience of young entrepreneurs. Besides, due to the increasing length of secondary school education between 1985 and 1994, there are fewer young entrepreneurs (5,6\% in 1994 were under 25 compared to $14 \%$ in 1985).

The intensity of entrepreneurship is mainly related to a responsibility status with firms also displaying a better life span. In the population of entrepreneurs, the proportion of employees and workers decreased between 1985 and 1994, whereas the proportion of executives in activity increased up until 1991, before being divided by half in 1994 (Bonneau and Francoz, 1996). Yet, thanks to their large representation in society, employees and workers still make up 40,5\% of the entrepreneurs of the Sine 1994 survey.

Entrepreneurs without secondary school qualifications represent about $60 \%$ of the sample while $73,5 \%$ in the population over 15 are people without secondary school qualifications. The level of education plays a significant role in the durability of the firm with a longer firm's life span for people with intermediate academic level. One possible explanation is that the lower the level of the diploma is, the more likelihood the new firm is a take-over (Bonneau and Francoz, 1996).

For 1000 people in activity (belonging to the working population), about 8 set up a new firm, but, for 1000 persons belonging to the non working population (over 15), only 1,5 persons set up a new firm. Our interpretation is that being in activity is favourable to an insertion into networks that facilitate entrepreneurship (taken opportunities, better view of the market, technical knowledge, etc.). We know that the share of wage earners that were employed when starting up decreased between 1985 and 1994 (they represent only 29\% of entrepreneurs in 1994 compared to $51 \%$ in 1985). This very likely represents the effect of unemployment.

Out of 1000 unemployed people, 32 set up their own company, that is about 6,5 times more than for the total population old enough to do so. This proportion has doubled between 1985 and 1994. This can be explained by the reduction in the opportunity cost of entrepreneurship. Most unemployed people start-up a firm under constraint, even though being unemployed may be for some of them the occasion to carry out a project they had been nurturing for a long time. Moreover 
the increase in the average length of unemployment may incite one to overcome the obstacle that a start-up represents as there is a risk of human capital depreciation.

Shapero (1975) shows that being unemployed breaks professional life and explains the increase of entrepreneurship. In the same way, he stresses other types of discontinuities with similar effects such as emotional shocks (getting divorced, belonging to a broken family, etc...) or cultural break-up (people of foreign origin). Hagen (1962) shows that the propensity to create a new firm among specific groups of population may be explained by the fact that they are deprived of their social status. This deprivation creates anxiety and anger that are transmitted along generations. These frustrations explain why most of these people have thus the desire to change their situation through entrepreneurship. This is the same situation in the case of immigration: the search for a social status, the willingness to be integrated in the society leads to entrepreneurship and to ethnocentric entrepreneurial behaviours.

With the Sine survey, we can see that the population of foreign origin (whether European or not) start up or take over a firm more frequently than the French population (about 2,5 times more). This feature may be the result of the integration difficulties that these populations may have, but it also points out to the ethnic networks that exist in some activities (Vietnamese and Chinese in the catering sector in some European countries). The percentage of foreign people among managers has been increasing over time in France (7\% in 1982 to 9,5\% in 1994, Bonneau and Francoz, 1996).

\section{Life Duration of New Firms}

We consider that the exit of the firm is globally constitutive of what we name an "entrepreneurial failure" in our population of young and small-sized firms. We characterize this entrepreneurial failure by the data analysis.

We check if the retained variables are relevant in the explanation of the two variables "State of the firm" (still running/closed down) and "Durability" which represent the life span of firms (still running/under 1 year life span/1-2 years/2-3 years/3-4 years). Explanatory variables are ranked according to their order of importance thanks to the "t-value" statistical criterion. The higher the "t- 
value" is, the more the variable characterizes in a significant way (at the usual level of 5\%) the durability of the firm (in two or five classes). All the selected variables are significant according to the life span of the firms (in two classes or in five classes). So they are all selected and they are gathered under three different themes which result from our vision of entrepreneurship.

\subsection{Characterization of entrepreneurship}

Entrepreneurship is viewed firstly as an individual involvement. Indeed, the identification of the firm with its manager is all the more higher as the firm is young and small. This can be explained by a personalized management and the fact that there is no counter power in this type of firms (no shareholders, no trade unions...). Furthermore, for some juridical types of firms (for example individual entrepreneur in the case of France), the fact that the wealth of the firm is not separated from the wealth of the entrepreneur reinforces the role of the personal characteristics of the entrepreneur.

So the first theme, called the "profile of the entrepreneur", takes into account the following variables: status of the entrepreneur (who starts up or who takes over a new firm), sex, age, professional status before the setting-up of the firm, previous occupation, academic level and nationality.

The second theme, called "the context of entrepreneurship" takes into account the conditions surrounding the entrepreneurship. These conditions are important for the future success of the new firm. It encompasses 14 variables, divided into three sub-groups.

1) The informational and technical context deals with the behaviour of the entrepreneur before the setting-up of his new firm when he was trying to get new skills and looking for information about the job itself. It is identified by five variables: obtaining advice, attending specific training programmes, carrying out specific surveys or studies, making contacts with potential customers $^{12}$, and getting skills during previous occupation.

2) The economic context sums up a set of variables linked to the size of the firm, its production and its geographical location. Studies show that there is a minimal efficient size 
which determines the survival of the firm. Taking into account the geographical location is justified by the fact that the urbanised regions show a stronger intensity in entrepreneurship and that there is a strong proportion of start-ups compared to take-overs. The economic context is made up of five variables: branch of industry, geographical location, size of the firm at the date of creation, subcontracting and number of customers.

3) The third sub-group, called the financial context, is justified by the existence of financing constraints affecting small firms as they often suffer from asymmetric information when they ask their bank for loans. The financial context takes into account four variables: asking for bank loans, obtaining bank loans, being granted public financial aid and the amount of money that was invested into the project.

Several studies show the importance of the entrepreneurial networks for the success of the new firm. These networks result from social reproduction (in particular, children taking-over the family firm). So the third theme, entitled "the degree of insertion of the entrepreneur in the entrepreneurial networks" is made up of five variables: the presence of relatives or close relations in these networks, the present exercise of an entrepreneurial function in another structure, the specific relations with customers, the specific relations with suppliers -which facilitate the setting-up of the firm- and the motivations of the entrepreneur. We retain the entrepreneurial motivations in this third theme because several modalities of this variable ("by the example of one's entourage", "opportunity" or "taste for entrepreneurship") are linked with the degree of insertion of the entrepreneur in the entrepreneurial networks.

Finally, based on each of these three themes, data analysis methods will enable us to explain the state of the firm (still running or closed down), the life span of the new firms being measured in classes and the duration of closed down firms being measured in months. 


\subsection{Methodology}

Data analysis methods enable us to collect a great number of variables so as to obtain the best summary of the information gathered in voluminous data basis. These methods prevent from making any a priori assumptions in the modelisation of the life span of the firms ${ }^{13}$.

For each of the three selected themes, we used two methods of structural data analyses to describe the state of the firm (closed down/still running) and the life span of the new firms in five classes.

The first method used to describe the state of the firm is a qualitative discriminant analysis (Saporta, 1977). This method is equivalent to a Discriminant Factorial Analysis (Fisher, 1936) on the factors of Multiple Correspondence Analysis (Benzecri, 1973) of the explanatory qualitative variables. It is an extension of the multiple regression in the case of an explained nominal variable with two modalities. This method allows us to determine and to rank the significant discriminant modalities of the selected explanatory variables for each of the three themes.

When explanatory variables are qualitative, the linear discriminating functions cannot be assessed directly (the matrix of the variables cannot be reversed) but the stability of the matrix due to the principal factors allows us to solve this difficulty. By a transformation of qualitative variables thanks to Multiple Correspondence Analysis, the discrimination on qualitative variables is equivalent to a discrimination on quantitative variables ${ }^{14}$. Applied to the factorial coordinates of the Multiple Correspondence Analysis, Fischer's Discriminant Analysis provides the discrimination model, that is to say the linear combination of the variables' modalities which leads to the best discrimination between the two groups of firms.

The second method is a Barycentric Discriminant Analysis. We applied an Ascendant Hierarchical Classification on the principal components of a Factorial Correspondence Analysis. In the cross table, the rows are made up of the five modalities of the variable life span we want to explain. The columns are built with a juxtaposition of the modalities of the explanatory variables of 
the selected theme. This method allows us to characterize the five classes of life span of the firm according to each of the three themes.

\subsection{Profile of the entrepreneur}

A Fischer's Discriminant Analysis was applied to the variables that constitute our first theme. The coefficients of the discriminant function and the coefficients of the equivalent regression, which discriminate significantly between closed down firms and firms still running, were ranked, according to the value of the t-student test, in table II. Moreover the sign of the coefficients indicates the state of the firm.

This method enables us to identify which modalities have a significant influence on the life span of the firm and the nature of the link (positive or negative). It becomes thus possible to build a forecasting model of the state of firms according to the features of the entrepreneur's profile.

\section{Insert TABLE II}

The model as a whole is significant since the $\mathrm{F}$ probability $\mathrm{P}(\mathrm{F}>92.68)=0.0001$ is lower than a risk level of $1 \%$.

We can note that the status of the entrepreneur and the previous occupation are very important because belonging to the working population and being an entrepreneur taking over an enterprise are the two most significant characteristic for the group of firms still running. The nationality (french), the level of diploma (over two years at University) and the age of the new entrepreneur (30-49 years old) appear as the main modalities associated to firms which are still running. In contrast, for the group of closed down firms, the main modalities are: the status of the entrepreneur (starting-up), the previous occupation (unemployed over one year), the nationality (Non European Union), the young age of the entrepreneur (under 25) and the lack of diploma.

So, an increasing age of the entrepreneur has a positive effect on the duration of the firm. This result is corroborated by a study of Cressy and Storey (1998) in which they demonstrate that the survival rate of firms increases with the age of the manager. This specific impact of age may be 
explained by a difficult access to external financing as well as a lack of experience (in the entrepreneurial function and in the branch of activity), constraints young creators are confronted to when first setting up a firm.

Second, to analyse the duration of the firms, we applied an Ascendant Hierarchical Classification. It allows us to ascertain with more precision the type of modalities which discriminate the five classes of duration. In figure I a clustered graphic tree summarizes this final classification.

\section{Insert Figure I}

The results of this analysis show that the highest heterogeneity is found between firms still running and closed down firms. In the group of closed down firms, heterogeneity concerns firms whose life span is under one year compared to the rest of the group. So we choose a partition in only 3 classes of homogeneous durability ${ }^{15}$ and we characterize each class.

The statistical description of the content of each class is given in table III. The standard profile of a class is based on comparisons of percentages of the modality in the class (FRE/CLA) and of this same modality out of the class (GLOBAL) taking into account the degree of inclusion of the class in the modality (CLA/FRE). The most characteristic modalities that come out of each class stems from the gap between the relative values of the class and the global values. These values are converted into a test-value criterion (V.Test). This last value is given in the table in a decreasing order with a risk of error (PROBA) less than 5\% which allows us to organize the most discriminant modalities of each class of life span.

\section{Insert TABLE III}

We can observe that in the class of firms with the shortest life span (under one year), the main characteristics of entrepreneurs are: unemployed or inactive (in his previous occupation or in his previous status), young (under 30 years old), starting-up, woman, no diploma, low level of responsibility in previous occupation etc... ${ }^{16}$. Besides, an academic level corresponding to the 
secondary school diploma and a status of middle management executive are specific modalities for this group.

We can draw some conclusions from the comparison between each class of life span. Startingup is a significant modality for the closed down firms while the modality taking over is significant for the firms which are still in activity. The same distinction appears for the variable "age of the entrepreneur": under 30 years is a significant modality for all the closed down firms while for the firms still running, we find older entrepreneurs (between 30-49 years). The modality "over 50 years old" is also characteristic of the 1 to 4 years life span. For the firms which are still running, they are entrepreneurs belonging to the working population and who are between 40-49 years (mature people).

Being unemployed, whatever the duration of unemployment, is significant for closed down firms. For the firms which are still in activity, the two modalities "unemployed for less or over one year" are not significant. Finally, for the groups of closed down firms and whatever the firm life span, the sex (woman) and the nationality of the entrepreneur (Non European Union) are characteristic.

\subsection{Context of entrepreneurship}

A discriminating analysis of the variable that indicates whether the firm is still running or closed down allows us to specify and to rank the modalities of the selected explanatory variables. The table IV presents the results of the analysis.

\section{Insert TABLE IV}

The first two modalities that make the difference between still running and closed down firms are two modalities of the variable number 16 which deals with skills acquired during previous activity. The skill "experience in the same branch" is related to firms still running. The skill "experience in different branch" is related to closed down firms. This variable seems to be a crucial variable. A possible explanation of this result would be that the entrepreneur makes full use of his experience if this experience has been acquired in the same branch of activity which means that the 
specific human capital of the entrepreneur has an effect on the survival of the firm when it is acquired in the same branch of activity. Likewise the general human capital of the entrepreneur measured by the level of education and belonging to the working population has also a positive effect on the life span of the firms (see table II).

The third modality ranking the firms is the granting of a loan by a bank, related of course to firms still running. Here we can conclude that the selection process of entrepreneurs and of their projects by banks is quite efficient. This selection process gives relevant information on the probability of the firm's survival. Another interpretation of this result refers to the phenomenon of bank credit rationing which mainly affects young and small French firms (Ciéply and Paranque, 1998). In such a perspective, the firms which were refused a loan have a lower survival rate which would be more the result of an exclusion of this population from the credit market than an efficient selection of the bank customers based on an individual risk analysis. The two other modalities of the bank loan variable, namely "refused" and "not asked for", are related to closed down units. The lower survival rate of the firms which didn't ask for any bank loans shows the existence of a selfexclusion from the credit market on the part of some of the entrepreneurs.

The next most significant modalities for the group of firms still running are those related to the amount of money that was invested and to the branch of industry. We find that the relatively high level of investment (over 15245 €uros) is related to the firms that survive whereas the low level of investment (less than 3811 €uros) is related to closed down firms. If level of investment is significant, the size of the firm at the date of creation is not except for the modality three persons. The firms which are still running belong to the following branches ; household services, transport, construction, services for enterprises, and industry while closed down firms belong to catering and trade branches.

Another interesting characteristic concerns the variable "subcontracting" where a high turnover in subcontracting is related to closed down firms while the two others modalities (medium turnover in subcontracting, never do) are related to the still running units. It may indicate that, for the contractor, new firms often absorb the cyclic fluctuations which implies a high variability in 
their turnover. The modality "one or two customers" of the variable "number of customers" also conforms to this result. Indeed, a new firm with few customers is probably a subcontracting firm.

Only the regions "Bretagne", "Auvergne" and "Bourgogne" are related to firms still running while the region "Île-de-France", which is the capital region, and which displays a particular development, is related to closed down firms.

Another interesting result is that obtaining public financial aid is representative of closed down units. This paradoxical result may be explained by the fact that the population concerned by public financial aid is a specific population more prone to failure. In 1994 about 80000 unemployed people obtained a public financial aid called $\mathrm{ACCRE}^{17}$. Yet this result must not be interpreted as the failure of public financial aid because a part of this aid incited some unemployed people to found a firm, and sometimes a successful one (cf. paragraph 3.6).

When the entrepreneur looked for advice it enabled him to increase the potentiality of surviving.

In figure II the ascendant hierarchical classification enables us to point out the modalities that are representative of our five classes of life span.

\section{Insert Figure II}

The main features of the four selected classes are the following ones. The very low amount of money invested (less than 3811 €uros) as well as the little number of employees are typical of firms with the shortest life span. The economic context shows that the fact of employing one or two persons tends to be representative of entrepreneurial failures for all classes of the life span of the firms. In the financial context we have the same result when one does not ask for a bank loan. "Getting public financial aid" appears to be characteristic of firms with a short life span (less than one year). The same conclusion applies to the modality "no training".

Southern regions of France, dealing with important migration flows, display a life duration of less than 2 years for "Provence-Alpes-Côte d'Azur" and between 2 and 4 years for "LanguedocRoussillon". Trade is characteristic of all the modalities of duration of the closed down firms. It is 
the same result for catering except for the group of under one year for which the modality catering doesn't appear.

The modality "no studies" of the variable carrying out specific surveys or studies is representative of firms which lasted less than two years.

\subsection{Insertion in the entrepreneurial networks}

Another last Fisher Linear Discriminant Analysis has been applied to the variables that constitute "the degree of insertion in the entrepreneurial networks". The modalities, which discriminate significantly between closed down firms and firms still in activity, have been ranked in table V.

\section{Insert TABLE $V$}

The significant modalities for firms still running refer to the opportunity motivation, the presence of relatives in the entrepreneurial "milieu", the present exercise of a managerial function or being a partner in another firm ${ }^{18}$, the taste of entrepreneurship and the relations with the customers. These results refer globally to an entrepreneurial profile of successful integration into the entrepreneurial networks. Entrepreneurship that benefits from entrepreneurial networks concerns greater size classes because they are usually accompanied by financial family support and they benefit of the entrepreneurial culture ${ }^{19}$. This insertion favours the duration of the firm (Gollac, M. and P. Lauhle, 1987). Success in entrepreneurship is also an incentive to create new structures to diversify the activity of the firm or to set up new structures for one's descendants.

The modality "Yes-relationships with suppliers" of the variable specific relations with suppliers is related to closed down firms. This result may indicate that these relationships are built by the suppliers with the objective of giving subcontracting works. By contrast, the modality "Yesrelationships with customers" is related to firms which are still running. In this case, we can suggest that this kind of relationships allows to improve the quality of the product sold by the new firm. 
In figure III the firms whose life span is under one year appear different from the other duration classes. On the other hand, the three classes corresponding to a life span from 1 to 4 years present the strongest similarity.

\section{Insert Figure III}

The main features of the three selected classes are the following ones. The lack of insertion in the entrepreneurial networks is characteristic of the firms with a life span of less than one year. It this class, the entrepreneur is totally isolated from entrepreneurial networks since he doesn't have any relationship with his customers and suppliers, is not a manager or a partner in another firm and doesn't benefit from an entrepreneurial entourage. Among the closed down firms, we can notice that relationships with suppliers appear to be representative of firms with a longer life span (over one year).

The unemployed motivation is characteristic of all the classes of closed down firms. Setting up a firm under constraint is therefore prejudicial to the durability of the new firm. Having an entourage who sets the example of starting a firm is not a factor of durability but only the presence of the sole family in the entrepreneurial networks is favourable to survival. This last point might be explained by the phenomenon of the passing on of craft firms between members of a same family.

\subsection{The specific case of public financial aid}

The paradoxical effect of public subsidies on the survival of firms should be analysed considering the specificity of the population who obtained these subsidies. So we examine first the effect of public financial aid on the state of firms at 4 years according to the previous activity of the entrepreneur ${ }^{20}$ in table VI.

\section{Insert TABLE VI}

Public financial aid is mainly focused on the category of unemployed people since their weight in the distribution of aid is greater than their size in the population of entrepreneurs. Globally $88 \%$ of the public financial aid is allocated to this category while unemployed people 
represent only $42 \%$ of the total population. Furthermore, we can observe that the positive effect of public financial aid on the state of the firm four years later is significant for the category of unemployed people and especially so for the category of unemployed people for under one year ${ }^{21}$. However, it is not significant for the non working population. The catching up effect noticed for assisted unemployed people does not however enable them to reach the survival rate of the firms started by unassisted working people.

Second, we analyse the effect of public financial aid on the life span of the firms which disappeared (28957 corrected units). An Analysis Of Variance (ANOVA) of the duration of the closed down firms has been made with two controlled factors (previous occupation, obtaining public financial aid) with interaction effect.

\section{Insert TABLE VII}

The differences in average life duration according to the modalities of previous occupation of the entrepreneur are more important than the differences according to the obtainment of public financial aid and we confirm these differences in a variance analysis the results of which are given in table VIII.

\section{Insert TABLE VIII}

Belonging to the working population or getting public financial aid have each a positive effect on the life span of the firms which were closed down after 4 years. On the other hand, not obtaining aid or the position of being unemployed for over one year decreases the life span of the firm.

For the incremental effect which appears when the two factors are simultaneously accounted for, the value of the Fisher test $(3,348)$ is significant at the threshold of 0,0181 (PROBA). Therefore we are led to reject the null hypothesis of an absence of an interaction effect. The factors "previous occupation" and "obtaining public financial aid" are not independent.

Thus the fact of being unemployed and also getting public financial aid lengthens the life span of firms (positive effect) and this whatever the duration of unemployment. A reverse effect is observed for unemployed people who do not get public financial aid (negative effect). Such interaction effects are not significant on the categories of the working and non-working populations. 
However we may note that the residual variance which is very important suggests that they are others important factors.

Our results are confirmed by a recent study based on the same survey (Crépon and Duguet, 2002). They measure how and for which type of entrepreneurs the combination of public financial aid and bank loans leads to an increase in the life duration of new firms. They found that for the working population, public financial aid has no significant effects on the life duration of the new firms. For the population of unemployed over one year, public financial aid is positive.

\section{Conclusion}

Taking an interest in new firms' life span appears to be all the more important when we know that new firms are characterized by a high mortality rate, half of them having stopped their activity before their fifth year of life. Such a feature is not restricted to France; survival rates of start-ups in the industrialized European countries are similarly low: only $65 \%$ of the start-ups live over three years, the proportion decreasing to $50 \%$ after five years.

Some specific characteristics of the entrepreneur and of the new firm discriminate between firms still running and closed down firms.

Closed down firms are characterized by the following modalities. As they are small projects (under 3811 €uros) with few customers, the young entrepreneur (often previously jobless) either does not care to look for a loan or has his loan refused by the bank. When he is experienced, he has acquired this experience in another branch of activity.

For the firms still running, the entrepreneur makes full use of his human capital by taking over a firm in the same branch of activity. When he sets up his firm, he launches important investment projects thanks to a bank loan.

Furthermore, our analysis shows that obtaining public financial aid improves the duration of the firm especially for the population of unemployed people. We can also notice that obtaining advice contributes to the lengthening of the life span of the firms. This last result may encourage further studies for a better specification of public policies according to the different categories of new entrepreneurs. 


\section{Annex 1: Dictionary of variables}

Variable number- Wight variable
1. (continued VARIABLE )

Theme 1 : Profile of the entrepreneur

2. Status of the entrepreneur
*Starting-up

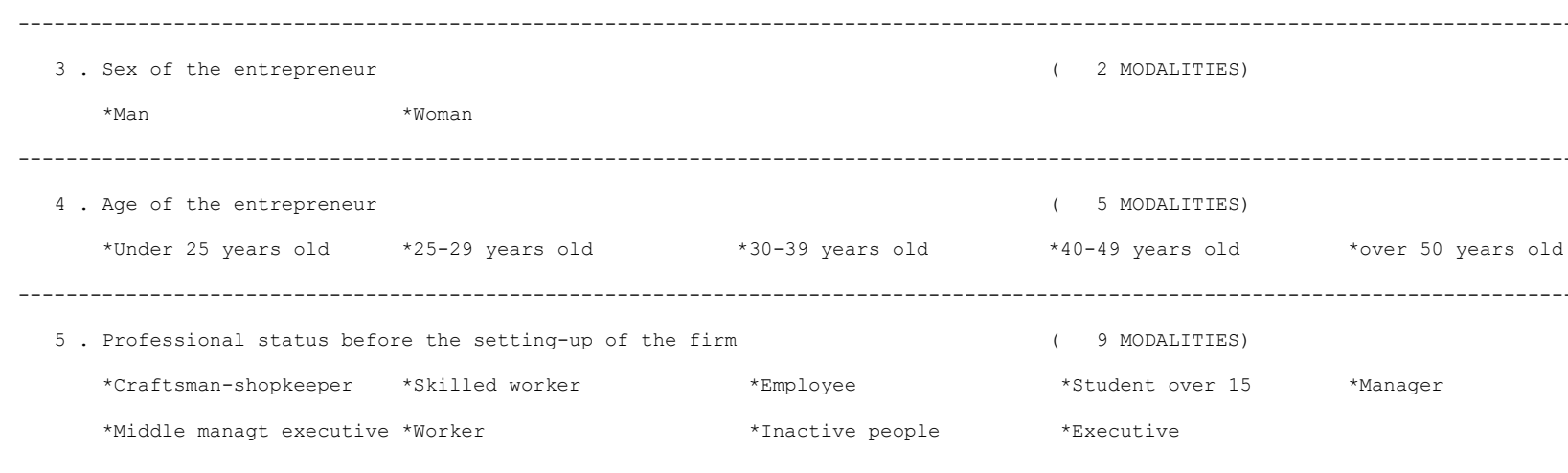

6 . Previous occupation before the setting-up of the new firm (4 ModaLITIES)

*Working population *Unemployed under 1 year *Unemployed over 1 year *Non working population

7 . Academic level
$\quad *$ Intermediate Level *Secondary School diploma *More than 2 years univ. Diploma *unqualified

8. Nationality

( 3 MODALITIES)

*French *European Union *Non European Union

Theme 2 : Context of entrepreneurship

\begin{tabular}{|c|c|c|c|}
\hline . Branch of industry & & & ( 8 MODALITIES) \\
\hline *Household services & *Industry & *Trade & *Services entreprises \\
\hline${ }^{\star}$ Construction & *Transports & ${ }^{*}$ Catering & *Food industry \\
\hline
\end{tabular}

10. French Regions

\begin{tabular}{|c|c|c|c|c|}
\hline *Ile-de-france & *Bourgogne & *Bretagne & *Rhône-Alpes & ${ }^{*}$ Champagne-Ardenne \\
\hline *Nord-pas-de-calais & *Poitou-Charentes & *Auvergne & ${ }^{\star}$ Picardie & *Lorraine \\
\hline *Aquitaine & *Languedoc-Roussillon & *Haute-Normandie & ${ }^{\star}$ Alsace & *Midi-Pyrénées \\
\hline *Prov.Alpes-Côte-Azur & ${ }^{*}$ Centre & *Franche-comté & ${ }^{\star}$ Limousin & *Pays de la Loire \\
\hline *Basse-Normandie & ${ }^{*}$ Corse & & & \\
\hline
\end{tabular}

11 . Size of the enterprise in 1994

( 5 MODALitiEs)

*one person *two persons *Three persons *four persons *five and more pers.

12 . Did you get any advice before setting-up your firm? ( 2 MODALITIES)

*yes advice *no advice

13. Did you attend specific training programmes before setting-up your firm? ( 4 MODALITIES)

*no training *yes under 5 days *yes between 5-15 days *yes over 15 days

14. Did you undertake specific study, survey etc. before setting-up your firm? ( 2 MODALITIES)

*yes studies $\quad$ *No studies

15. Did you make contacts with customers before setting-up your firm? ( 2 MODALITIES)

*yes customers *no customers

16. In which branch did you acquired skills during your previous occupational activity? 5 MODALITIES) 
prev.act.

17. Did you obtain public financial aid?

( 3 MODALITIES)

*yes aid

* no aid

*waiting for answer

18 . What is the amount of money you invested to set-up your firm?

( 4 MODALITIES)

*less $3811 €$

*3811 $€$ to $15245 €$

*15245 € to $76225 €$

*over $76225 €$

19 . Did you ask for bank loans?

( 2 MODALITIES)

*yes loans asked

*no loans asked

20. Did you obtain any bank loans?

( 3 MODALITIES)

*yes, obtained loans

*no, obtained loans

*no, asked for loans

21 . Do you get work as a subcontractor for other firms?

( 3 MODALITIES)

*never do sub-contra. *yes medium source turnover *yes main source turnover

22 . How many customers do you have?

( 3 MODALITIES)

*1 or 2 customers *3 to 10 customers 10 customers

Theme 3 : Degree of insertion of the entrepreneur in the entrepreneurial networks

23. Was the setting-up of your firm facilitated by relationships with suppliers? ( 2 MODALITIES) *yes relat. Suppliers *no relat. Suppliers

24. Was the setting-up of your firm facilitated by relationships with customers? ( 2 MODALITIES) *yes relat. Customers *no relat. Customers

25. Do/did you have people in your surrounding who are/were entrepreneurs themselves? (4 MODALITIES)
*relatives or close
*relatives only
*close relat. Only
*no close no relatives

26. Are you manager or partner in an other firm?

( 2 MODALITIES)

*yes manager or part. *no manager or part.

27 . What was your main motivation when you set-up your firm?

( 5 MODALITIES)

$\star_{\text {New }}$ ide

*opportunity

*Unemployed

*Entourage example

*Taste for entrepren.

\section{Theme 4: life span of the new firms}

28. Life span of the firm - State (closed down / still running)

( 2 MODALities)

*Closed down firms *Still running firms

29. Life span of the firm - Classes

( 5 MODALities)

*under 1 year

*1-2 year life span

*2-3 year life span

*3-4 year life span

*Still running firms 


\title{
Acknowledgements
}

\author{
We are grateful to Professor Bernard Franck for helpful comments and suggestions. The
}

usual disclaimer applies.

\section{Notes}

1 There were 218577 start-ups and takeovers in 2001 and they created about 462094 jobs.

2 The total stock of SME's increased by $25 \%$ between 1987 and 1992 according to the source SIRENE ("Systeme d'Informations et de Répertoire des Entreprises et des Etablissements") - Information and registration system of firms and plants-; from the National Institute of Statistics and Economic Studies (INSEE). The rise was especially significant in the services sector. In the industrial sector, the number of small and medium sized enterprises grew from 48629 in 1987 to 53070 in 1992 , that is to say a rise of $9,13 \%$.

3 "Start-ups" refer exclusively to new business starts, excluding takeovers. When we speak of "new firms" or "new enterprises", we refer both to start-ups and takeovers. Likewise, "entrepreneur" is used both for people who start-up firms and for people who take one over.

4 The reduction in the opportunity cost of entrepreneurship has contributed to a revival in entrepreneurship since approximately forty percent of entrepreneurs were formerly unemployed.

5 The propensity for entrepreneurship can be measured by the ratio of new firms to the working population. If we compare with other countries, there is a weak propensity for entrepreneurship in France. For example, in 1997, the ratio was 1,75 higher in the USA and 1,4 higher in the United-Kingdom than in France.

6 This empirical literature on post-entry survival refers to numerous articles : Evans (1987), Dunnes and Hugues (1994), Mata and Portugal (1994), Wagner (1994), Mata and Portugal and Guimaraes (1995), Audretsch (1995), Audretsch and Mahmood (1995), Boeri and Bellman (1995), Doms, Dunnes and Roberts (1995), Mc Cloughan and Stone (1998), Nucci (1999), Mahmood (2000), Honjo (2000), Eide and Tveteras (2000)...

7 "Système d'information sur les nouvelles entreprises" (The information system on new firms).

8 Insee (Institut National des Statistiques et des Etudes Economiques).

9 We exclude "activations" and "reactivations" from the sample. Economic "activations" correspond to Sirene listed units yet which had not any activity and which decide to exercise one. Economic "reactivations" correspond to Sirene listed units which had stopped their activity and which start up again (they only deal with individual entrepreneurs craftsmen or shopkeepers-). The surveyed firms have survived at least for one month.

10 The sample was built by randomly drawing out samples from the 416 (2x8x26) elementary strata. These strata are classified according to the origin (start-up or takeover: 2 modalities), the branch ( 8 modalities) and the localization (22 French regions plus 4 overseas departments). The data basis must then be used with the correction of a weight variable (the reverse of the draw rate per branch, per region and per origin). Originally the sample is representative of the total population of entrepreneurs which was 96407 new firms.

11 A more precise information on variables of the survey Sine is available from the authors upon request.

12 This variable is retained as representative of the informational context at the time of creation because it enables one to know whether the entrepreneur has been seeking information about the market or about the existence of potential customers.

13 "The model must follow data but not the contrary"(Benzecri, 1973).

14 Indeed, in a first step, we synthesise all the links between the modalities of explanatory variables thanks to principal factors of the Multiple Correspondence Analysis. In a second step we only select the most discriminant principal factors.

15 We use the Generalized Ward's Criterion based on the criterion of the minimal loss of inertia.

16 When we introduce the branch of industry as supplementary variable, we observe that this profile corresponds to trade sector.

17 Aides aux Chômeurs Créateurs-Repreneurs d'Entreprises.

18 According to Moran (1999), the previous experience in the management of an enterprise is also important to explain the strong growth of the new firm.

19 According to Volery and Servais (2001), the entrepreneurial culture facilitates entrepreneurship with an important initial size of the project.

20 Entrepreneurs still waiting for public financial aid were not included.

21 Charpail and Simon (1999) find that the unemployed people who obtained a public financial aid have a greater chance of survival in comparison with the whole of the creators unemployed population. 


\section{References}

Audretsch, David B., 1995, Innovation and Industry Evolution, The MIT Press, Cambridge, Massachusetts.

Audretsch, David B., 1995, "Innovation, growth and survival", International Journal of Industrial Organization, 13, 441-457.

Audretsch, David B. and Talat Mahmood, 1995, "New firm survival : new results using a hazard function", Review of Economics and Statistics, 77, 97-103.

Benzecri, Jean Paul, 1973, L'analyse des correspondances, Dunod, Tome 2, Paris.

Birch, David L., 1983, The contribution of small enterprise to growth and unemployment, Cambridge, MA: M.I.T. program on neighbourhood and regional change.

Boeri, Tito and Lutz Bellman, 1995, "Post-entry behaviour and the cycle: evidence from Germany", International Journal of Industrial Organization, 13, 473-502.

Bonneau, Jacques and Dominique Francoz, 1996, "Les caractéristiques socioéconomiques des créateurs d'entreprises", Données Sociales, Insee, 174-180.

Charpail, C., and M.O. Simon, 1999, "La situation des entreprises créées en 1994 par des chômeurs bénéficièrent d'une aide publique", Premières Synthèses, Insee, 51 (2), december, 1-8.

Ciéply, Sylvie and Bernard Paranque, 1998, "Le rationnement des petites entreprises sur le marché du crédit, mythe ou réalité", Banques et Marché, 33, avril.

Crépon Bruno and Emmanuel Duguet, 2002, "Prêt bancaire, aides publiques et survie des nouvelles entreprises : une analyse économétrique à partir des méthodes d'appariement sélectif sur données d'entrepreneurs", Cahiers de la MSE, $\mathbf{n}^{\circ} \mathbf{4 8}, 42$ p.

Cressy, Robert and David Storey, 1998, New firms and their banks, Rassegna-Economica; 62(1), 213-45.

Doms, Mark, Dunne, Timothy and Mark J. Roberts, 1995, "The role of technology in the survival and growth of manufacturing plants", International Journal of Industrial Organization, 13, 523542 .

Du Rietz, Anita and Magnus Henrekson, 2000, "Testing the female underperformance hypothesis“, Small Business Economics, 14, 1-10.

Dunne, Paul and Alan Hughes, 1994, "Age, size, growth and survival: UK companies in the 1980s", Journal of Industrial Economics, XLII (2), June, 115-140.

Eide, Geir and Ragnar Tveteras, 2000, "Survival of new plants in different industry environments in Norwegian manufacturing : a semi-proportional Cox model approach", Small Business Economics, 14, 65-82.

Evans, David S., 1987, "The relationship between firm growth, size and age: estimates for 100 manufacturing industries", The Journal of Industrial Economics, XXXV (4), June, 567-581.

Gollac, Michel and Pierre Lauhle, 1987, "La transmission du statut social : l'échelle et le fossé", Economie et Statistique, 199-200, 85-93.

Fisher, R.A., 1936, "The use of multiple measurements in taxonomic problems ". Ann. Of Eugenics, 7, 179-188.

Hagen, E., 1962, On the theory of the social change, Homewood, Illinois, Dorset Press.

Honjo, Yuii, 2000, "Business failure of new firms : an empirical analysis using a multiplicative hazards model", International Journal of Industrial Organization, 18, 557-574.

Mahmood, Talat, 2000, "Survival of newly founded businesses: a log-logistic model approach", Small Business Economics, 14, 223-237. 
Mata, José and Pedro Portugal, 1994, "Life duration of new firms", Journal of Industrial Economics, 42 (3), 227-245.

Mata, José, Portugal Pedro, and Paulo Guimaraes, 1995, "The survival of new plants: start-up conditions and post-entry evolution”, International Journal of Industrial Organization, 13, 459481.

Mc Cloughan, Patrick and Ian Stone, 1998, "Life duration of foreign multinational subsidiaries: evidence from UK northern manufacturing industry 1970-93", International Journal of Industrial Organization, 16, 719-747.

Moran, Paul, 1999, "The influence of Owner-Manager personality on small business growth", Network of International Business Schools, Rennes, September.

Nucci, Alfred R., 1999, "The demography of business closings", Small Business Economics, 12, 2539.

Saporta, G., 1977, "Une méthode et un programme d'analyse discriminante sur variables qualitatives", In Premières Journées Internationales , Analyse des données et informatique, INRIA, Rocquencourt.

Shapero, A., 1975, "The displaced, uncomfortable entrepreneur", Psychology Today, 9 (6), 83-88.

Volery, T. and I. Servais, 2001, "Rapport 2000 sur l'entrepreneuriat en France", Global Entrepreneurship Monitor (G.E.M.), Ecole de Management, Lyon. 
TABLE I Attributes of entrepreneurs.

\begin{tabular}{|c|c|c|c|c|}
\hline \multicolumn{2}{|c|}{ Socio-economic features of the entrepreneur } & \multirow{2}{*}{$\begin{array}{l}\text { In proportion of new firms } \\
\text { (Sine 1994) } \\
69,40 \%\end{array}$} & $\begin{array}{c}\text { In proportion of firms still } \\
\text { running after } 4 \text { years (Sine } \\
1997 \text { ) }\end{array}$ & \multirow{2}{*}{$\begin{array}{l}\text { In proportion of the } \\
\text { over } 15 \text { population } \\
\text { (in } 1997)^{\mathbf{a}} \\
48,1 \%\end{array}$} \\
\hline & Man & & $71,62 \% * *+$ & \\
\hline 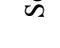 & Woman & $30,60 \%$ & $28,38 \% * * *$ & $51,9 \%$ \\
\hline \multirow{5}{*}{$\stackrel{8}{\ll}$} & Under 25 & $5,57 \%$ & $3,87 \% \quad * *_{-}$ & $18,52 \%$ \\
\hline & 25-29 years old & $19,46 \%$ & $17,74 \% * *_{-}$ & $9,39 \%$ \\
\hline & $30-39$ years old & $34,05 \%$ & $35,43 \% * *+$ & $18,66 \%$ \\
\hline & 40-49 years old & $28,27 \%$ & $30,30 \% * *+$ & $15,97 \%$ \\
\hline & 50 years old and over & $12,66 \%$ & $12,66 \%$ & $37,46 \%$ \\
\hline \multirow{9}{*}{ 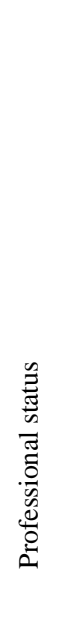 } & Craftsman, shopkeeper & $13,36 \%$ & $15,72 \% * *+$ & $6,5 \%$ \\
\hline & Manager & $6,27 \%$ & $6,88 \% \quad * *+$ & $0,3 \%$ \\
\hline & Executive & $17,45 \%$ & $18,74 \% * *+$ & $3,8 \%$ \\
\hline & Skilled worker & $4,54 \%$ & $4,46 \%$ & $3,2 \%$ \\
\hline & Middle management executive & $6,39 \%$ & $6,37 \%$ & $9,8 \%$ \\
\hline & Employee & $26,68 \%$ & $24,48 \% * *_{-}$ & $16,1 \%$ \\
\hline & Worker & $13,75 \%$ & $14,08 \% * *+$ & $14,4 \%$ \\
\hline & Student (over 15) & $3,74 \%$ & $3,57 \% * *_{-}$ & \\
\hline & Non working population & $7,82 \%$ & $5,70 \% * *_{-}$ & \\
\hline \multirow{4}{*}{ 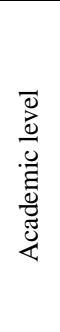 } & Unqualified & $20,70 \%$ & $18,02 \% * *_{-}$ & $42,71 \%$ \\
\hline & Intermediate level & $38,61 \%$ & $38,91 \% *+$ & $30,88 \%$ \\
\hline & Secondary school diploma & $15,48 \%$ & $15,15 \% * *_{-}$ & $10,33 \%$ \\
\hline & $\begin{array}{c}\text { Diploma received after two years at } \\
\text { University }\end{array}$ & $25,20 \%$ & $27,92 \% * *_{+}$ & $16,07 \%$ \\
\hline \multirow{4}{*}{ 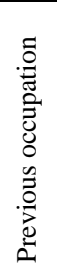 } & Working population & $44,66 \%$ & $51,23 \% * *+$ & $47,70 \%$ \\
\hline & Unemployed - under one year & $26,24 \%$ & $24,96 \% * *_{-}$ & $4,10 \%$ \\
\hline & Unemployed - over one year & $15,64 \%$ & $13,04 \% * *_{-}$ & $2,61 \%$ \\
\hline & Non working population & $13,46 \%$ & $10,78 \% * *_{-}$ & $45,60 \%$ \\
\hline \multirow{3}{*}{ 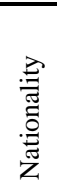 } & French & $90,37 \%$ & $92,18 \% * *+$ & $94,2 \%$ \\
\hline & European Union & $3,95 \%$ & $3,82 \%$ & $2,5 \%$ \\
\hline & Non European Union & $5,68 \%$ & $4 \% \quad * *_{-}$ & $3,3 \%$ \\
\hline
\end{tabular}

** Significance less than $1 \%, \quad *[1 \%-5 \%],+$ rather more firms still running, - rather more closed down firms

a For the age variable the data are from 1990. For the Professional Status variable, the data are from 1996. For the nationality variable, the data are from 1999. 
TABLE II Linear Discriminant Analysis Model

Theme "Profile of the entrepreneur".

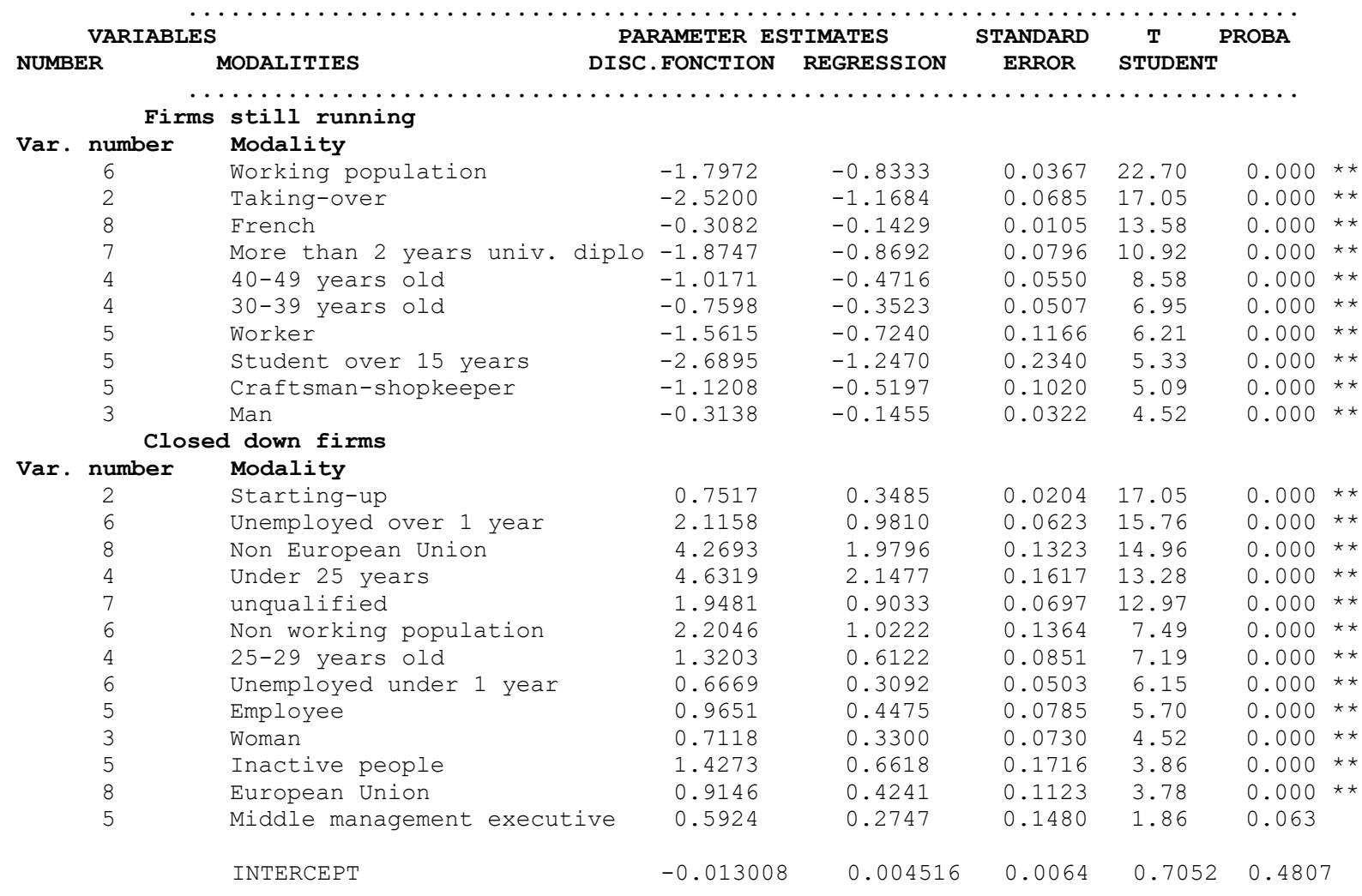

${ }_{F}=92.68234 \quad{ }_{\mathrm{PROBA}}=m_{0.0001}$

Significance only less than $10 \%:{ }^{*}$ less than $1 \%,{ }^{*}[1 \%-5 \%]$ 
Fig I. Hierarchical Tree of the life span of the firms according to the theme "Profile of the entrepreneur".

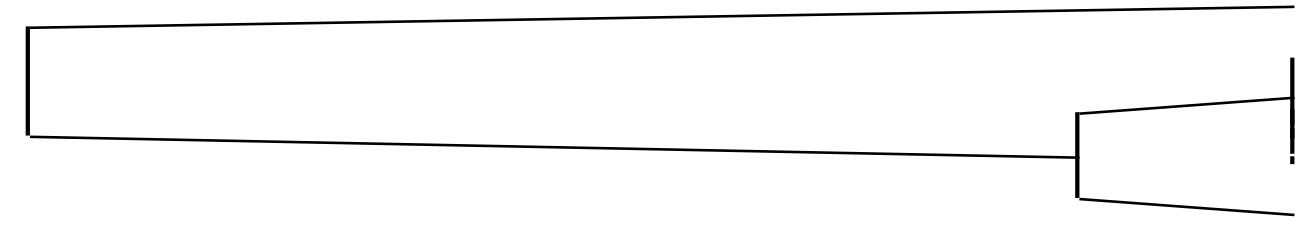

Livg : Living : 55

3-4 : 3-4 year : 1

2-3 : 2-3 year : 1

$1-2: 1-2$ year : 1

$<1$ : less 1 year 
TABLE III Typology of the life span of the firms - Characterization of the 3 classes according to the theme "profile of the entrepreneur".

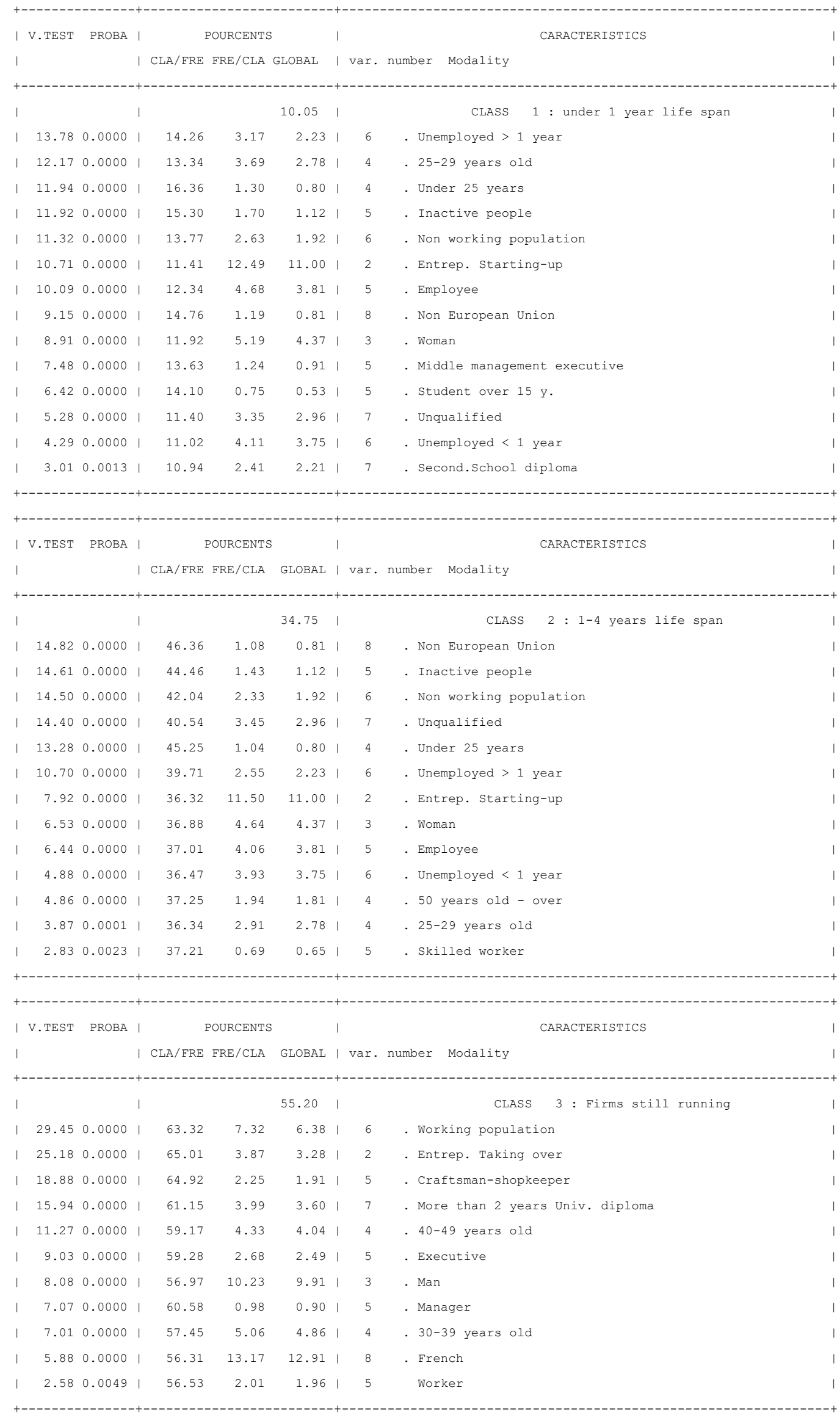


TABLE IV Linear Discriminant Analysis Model

Theme "Context of entrepreneurship".

\begin{tabular}{|c|c|c|c|c|c|c|c|c|}
\hline \multicolumn{3}{|c|}{ VARIABLES } & \multicolumn{2}{|c|}{ PARAMETER ESTIMATES } & \multirow{2}{*}{$\begin{array}{l}\text { STANDARD } \\
\text { ERROR }\end{array}$} & \multirow{2}{*}{$\underset{\text { STUDENT }}{\text { T }}$} & \multicolumn{2}{|c|}{ ROBA } \\
\hline NUMB & & MODALITIES & DISC.FONCTION & REGRESSION & & & & \\
\hline \multicolumn{9}{|c|}{ Firms still running } \\
\hline \multirow[t]{23}{*}{ Var. } & number & Modality & & & & & & \\
\hline & 16 & Same branch & -3.8300 & -1.7199 & 0.0738 & 23.31 & 0.000 & $\star \star$ \\
\hline & 18 & Over $76225 €$ & -8.7869 & -3.9458 & 0.2968 & 13.29 & 0.000 & $\star \star$ \\
\hline & 20 & Yes obtained loans & -2.5263 & -1.1345 & 0.0860 & 13.19 & 0.000 & $\star \star$ \\
\hline & 18 & 15245 to $76225 €$ & -3.4900 & -1.5672 & 0.1410 & 11.12 & 0.000 & $\star \star$ \\
\hline & 9 & Household services & -4.4010 & -1.9763 & 0.1935 & 10.21 & 0.000 & $\star \star$ \\
\hline & 22 & Over 10 customers & -0.8277 & -0.3717 & 0.0384 & 9.69 & 0.000 & $\star \star$ \\
\hline & 15 & No customers & -1.1918 & -0.5352 & 0.0585 & 9.15 & 0.000 & $\star \star$ \\
\hline & 9 & Transports & -6.9539 & -3.1227 & 0.3688 & 8.47 & 0.000 & $\star \star$ \\
\hline & 19 & Yes loans asked & -1.2894 & -0.5790 & 0.0701 & 8.26 & 0.000 & $\star *$ \\
\hline & 9 & Construction & -2.7879 & -1.2519 & 0.2235 & 5.60 & 0.000 & $\star \star$ \\
\hline & 9 & Services entreprises & -2.2352 & -1.0037 & 0.1876 & 5.35 & 0.000 & $\star \star$ \\
\hline & 21 & yes medium sub-cont. & -2.1378 & -0.9600 & 0.1885 & 5.09 & 0.000 & $\star \star$ \\
\hline & 10 & Bretagne & -3.1967 & -1.4355 & 0.3584 & 4.01 & 0.000 & $\star \star$ \\
\hline & 17 & No aid & -0.4781 & -0.2147 & 0.0574 & 3.74 & 0.000 & $\star \star$ \\
\hline & 9 & Industry & -2.0713 & -0.9301 & 0.2689 & 3.46 & 0.001 & $\star \star$ \\
\hline & 12 & Yes advice & -0.4856 & -0.2181 & 0.0698 & 3.13 & 0.002 & $\star \star$ \\
\hline & 10 & Auvergne & -2.6810 & -1.2039 & 0.4631 & 2.60 & 0.009 & $\star \star$ \\
\hline & 10 & Bourgogne & -1.6722 & -0.7509 & 0.3590 & 2.09 & 0.036 & $\star$ \\
\hline & 21 & Never do sub-contra. & -0.2066 & -0.0928 & 0.0443 & 2.09 & 0.036 & * \\
\hline & 13 & yes under 5 days & -0.9037 & -0.4058 & 0.1999 & 2.03 & 0.042 & $\star$ \\
\hline & 11 & Three persons & -1.1088 & -0.4979 & 0.2526 & 1.97 & 0.049 & $\star$ \\
\hline & \multicolumn{8}{|c|}{ Closed down firms } \\
\hline Var. & number & Modality & & & & & & \\
\hline & 16 & Different branch & 6.1506 & 2.7619 & 0.1709 & 16.16 & 0.000 & $\star \star$ \\
\hline & 22 & 1 or 2 customers & 7.3702 & 3.3096 & 0.2392 & 13.83 & 0.000 & $\star \star$ \\
\hline & 9 & Catering & 7.7648 & 3.4869 & 0.2762 & 12.63 & 0.000 & $\star \star$ \\
\hline & 18 & Less $3811 €$ & 3.5103 & 1.5763 & 0.1309 & 12.04 & 0.000 & $\star \star$ \\
\hline & 9 & Trade & 3.1649 & 1.4212 & 0.1208 & 11.77 & 0.000 & $\star \star$ \\
\hline & 20 & No obtained loans & 8.2591 & 3.7088 & 0.3834 & 9.67 & 0.000 & $\star \star$ \\
\hline & 21 & Main source turnover & 3.9541 & 1.7756 & 0.1849 & 9.61 & 0.000 & $\star \star$ \\
\hline & 16 & No answ. no prev. act. & 4.5467 & 2.0417 & 0.2132 & 9.58 & 0.000 & $\star \star$ \\
\hline & 15 & Yes customers & 1.8715 & 0.8404 & 0.0918 & 9.15 & 0.000 & $\star \star$ \\
\hline & 19 & No loans asked & 0.6730 & 0.3022 & 0.0366 & 8.26 & 0.000 & $\star \star$ \\
\hline & 20 & No asked for loans & 0.6730 & 0.3022 & 0.0366 & 8.26 & 0.000 & $\star \star$ \\
\hline & 18 & 3811 to $15245 €$ & 1.4363 & 0.6450 & 0.0931 & 6.93 & 0.000 & $\star \star$ \\
\hline & 16 & Close for your partner & 4.5224 & 2.0308 & 0.3684 & 5.51 & 0.000 & $\star \star$ \\
\hline & 17 & Waiting for answer & 4.0158 & 1.8033 & 0.4096 & 4.40 & 0.000 & $\star \star$ \\
\hline & 12 & No advice & 0.5450 & 0.2447 & 0.0783 & 3.13 & 0.002 & $\star \star$ \\
\hline & 10 & Ile-de-france & 0.7999 & 0.3592 & 0.1242 & 2.89 & $0.004 *$ & $\star \star$ \\
\hline & 13 & Yes between $5-15$ days & 1.2538 & 0.5630 & 0.2243 & 2.51 & 0.012 & $\star$ \\
\hline & 17 & yes aid & 0.5246 & 0.2356 & 0.1127 & 2.09 & 0.037 & $\star$ \\
\hline & 10 & Languedoc-Roussillon & 1.1997 & 0.5387 & 0.2871 & 1.88 & 0.061 & \\
\hline & 16 & Close branch & 0.7272 & 0.3266 & 0.1870 & 1.75 & 0.081 & \\
\hline & 11 & One person & 0.3303 & 0.1483 & 0.0877 & 1.69 & 0.091 & \\
\hline & & INTERCEPT & -0.024315 & 0.006491 & 0.0064 & 1.0133 & 0.3109 & \\
\hline & & $\cdots \cdots \cdots \cdots \cdots \cdots \cdots$ & $=\cdots \cdots$ & $\begin{array}{r}\cdots \cdots \\
\mathrm{PROBA}=\end{array}$ & $\begin{array}{r}\cdots \\
\quad 0.0001\end{array}$ & $\cdots \cdots$ & & \\
\hline
\end{tabular}


Fig II. Hierarchical Tree of the life span of the firms according to the theme "Context of entrepreneurship".

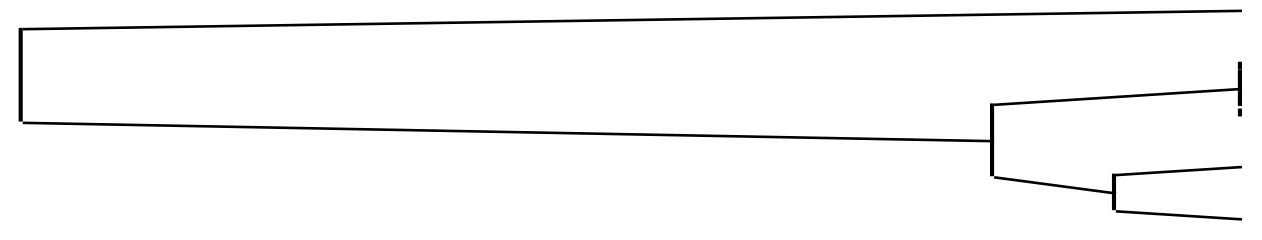

Livg : Living : 55

3-4 : 3-4 year : 1

$2-3: 2-3$ year : 1

1-2 : 1-2 year: 1

$<1$ : less 1 year 
TABLE V Linear Discriminant Analysis Model

Theme "Degree of insertion of the entrepreneur in the entrepreneurial networks".

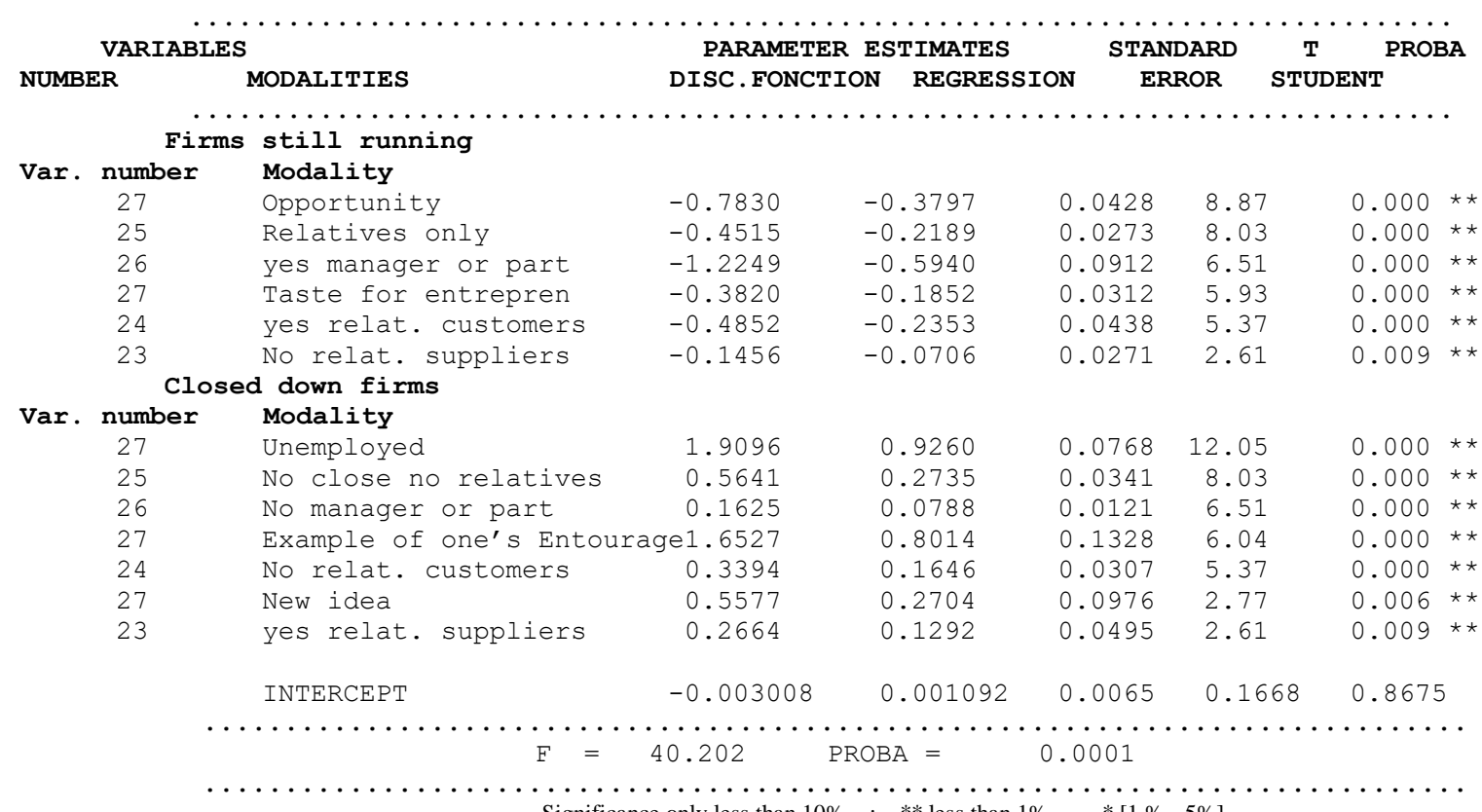

Significance only less than $10 \% \quad: \quad * *$ less than $1 \%, \quad *[1 \%-5 \%]$ 
Fig III. Hierarchical Tree of the life span of the firms according to the theme

"Degree of insertion of the entrepreneur in the entrepreneurial networks"

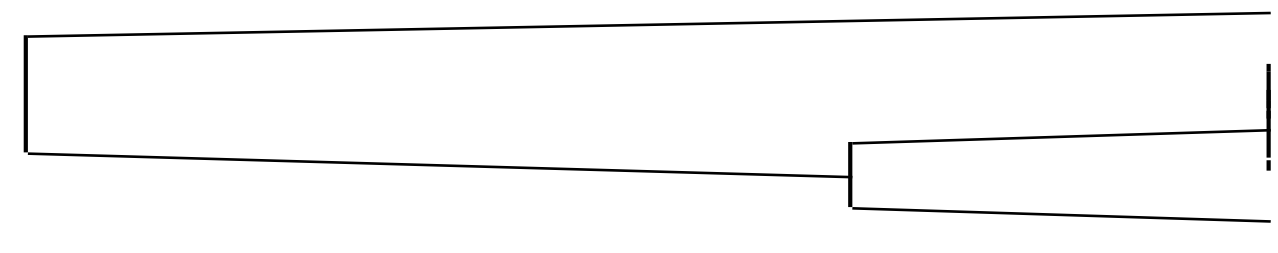

Livg : Living : 55

2-3 : 2-3 year : 1

3-4 : 3-4 year : 1

1-2:1-2 year: 1

$<1$ : less 1 year 
TABLE VI Obtaining public financial aid, previous activity of the entrepreneur and survival of the firm.

\begin{tabular}{|c|c|c|c|c|c|}
\hline & & Entrepreneurs in 1994 & $\begin{array}{l}\text { Entrepreneurs who } \\
\text { obtained public } \\
\text { financial aid in } 1994\end{array}$ & $\begin{array}{l}\text { Firms still running } \\
\text { after } 4 \text { years which } \\
\text { obtained aid }\end{array}$ & $\begin{array}{c}\text { Firms still running } \\
\text { after } 4 \text { years which not } \\
\text { obtained aid }\end{array}$ \\
\hline \multirow{4}{*}{ 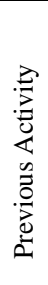 } & Working population & $44,66 \%$ & $9,84 \%$ & $70,00 \% * *+$ & $62,86 \%$ \\
\hline & Unemployed - under one year & $26,24 \%$ & $57,81 \%$ & $57,34 \% * *+$ & $39,60 \%$ \\
\hline & Unemployed - over one year & $15,64 \%$ & $29,69 \%$ & $48,74 \% * *+$ & $42,28 \%$ \\
\hline & Non working population & $13,46 \%$ & $2,66 \%$ & $44,33 \%$ & $43,99 \%$ \\
\hline
\end{tabular}

** Significance less than $1 \%, \quad *[1 \%-5 \%],+$ rather more firms still running 
TABLE VII Repartition of the mean duration of closed down firms according to the factors "Previous occupation" and "Obtaining public financial aid".

\begin{tabular}{|c|c|c|c|c|}
\hline \multirow{2}{*}{\multicolumn{2}{|c|}{$\begin{array}{c}\text { Duration of closed down firms - months- } \\
\text { Frequency } \\
\text { Mean } \\
\text { Standard Deviation }\end{array}$}} & \multicolumn{2}{|c|}{ Obtaining public financial aid } & \multirow[b]{2}{*}{ Total } \\
\hline & & Yes aid & No aid & \\
\hline \multirow{4}{*}{ 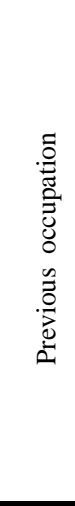 } & Working population & $\begin{array}{c}627 \\
25.22 \\
11.59\end{array}$ & $\begin{array}{l}10113 \\
25.13 \\
12.47\end{array}$ & $\begin{array}{l}10740 \\
25.14 \\
12.42\end{array}$ \\
\hline & Unemployed - under one year & $\begin{array}{l}5235 \\
24.28 \\
12.55 \\
\end{array}$ & $\begin{array}{l}2684 \\
21.85 \\
12.74 \\
\end{array}$ & $\begin{array}{l}7919 \\
23.46 \\
12.67 \\
\end{array}$ \\
\hline & Unemployed - over one year & $\begin{array}{l}3229 \\
23.36 \\
12.38\end{array}$ & $\begin{array}{l}2093 \\
20.72 \\
12.67 \\
\end{array}$ & $\begin{array}{l}5322 \\
22.32 \\
12.56 \\
\end{array}$ \\
\hline & Non working population & $\begin{array}{r}314 \\
22.91 \\
11.60 \\
\end{array}$ & $\begin{array}{l}4662 \\
23.61 \\
12.92 \\
\end{array}$ & $\begin{array}{c}4976 \\
23.563 \\
12.840 \\
\end{array}$ \\
\hline & Total & $\begin{array}{l}9405 \\
23.98 \\
12.41\end{array}$ & $\begin{array}{l}19552 \\
23.85 \\
12.73\end{array}$ & $\begin{array}{l}28957 \\
23.89 \\
12.63\end{array}$ \\
\hline
\end{tabular}


TABLE VIII The effect of public financial aid and previous activity on the life duration of closed down firms.

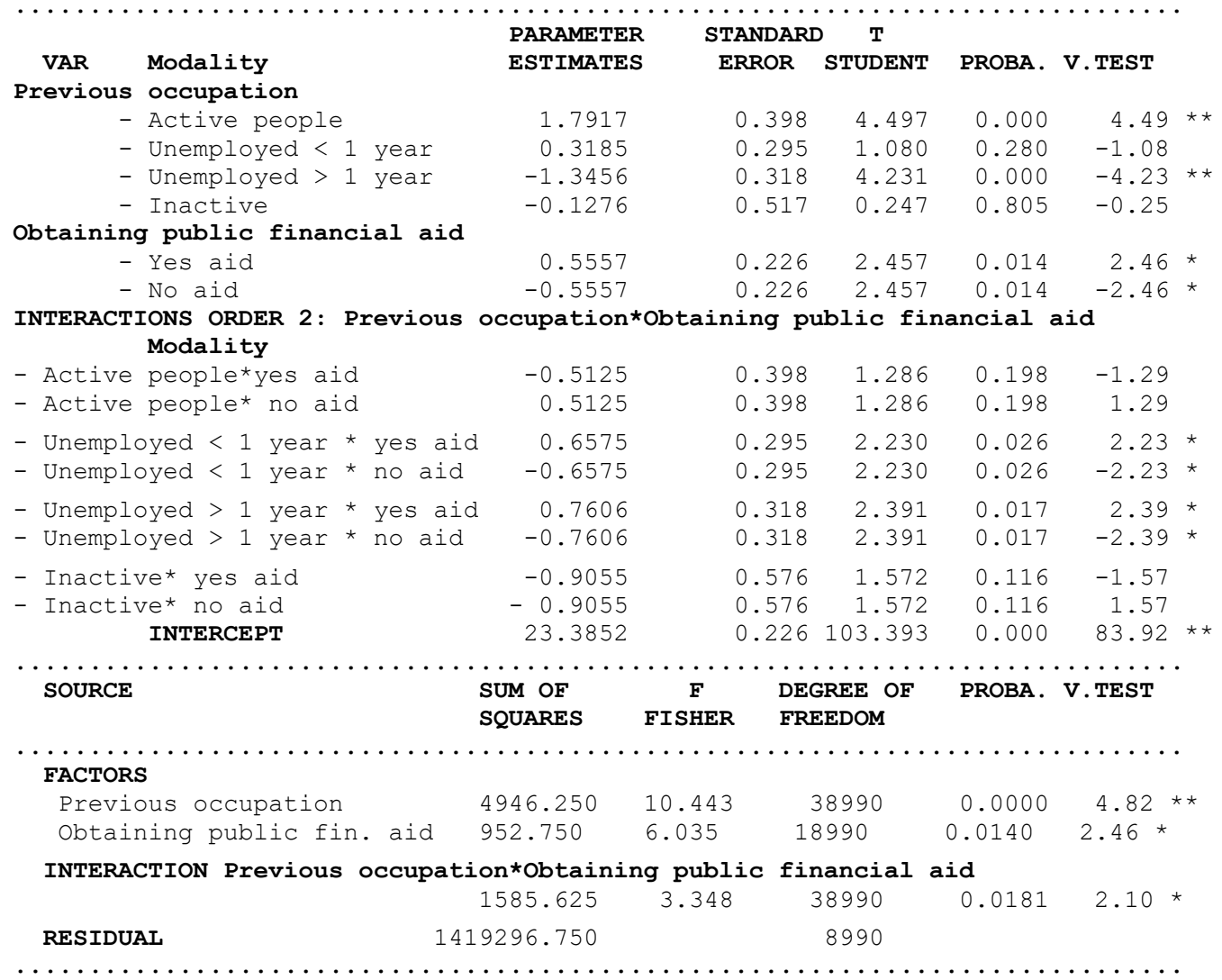

$* *$ Significance less than $1 \%, \quad *[1 \%-5 \%]$ 